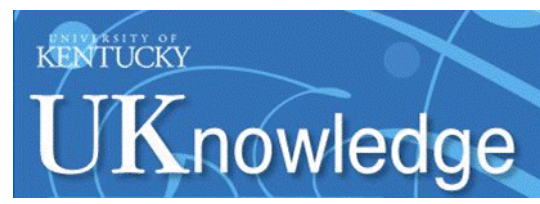

University of Kentucky

UKnowledge

\title{
Zircon U-Pb Geochronology of Two Basement Cores (Kentucky, USA): Implications for Late Mesoproterozoic Sedimentation and Tectonics in the Eastern Midcontinent
}

\author{
David P. Moecher \\ University of Kentucky, moker@uky.edu \\ J. Richard Bowersox \\ University of Kentucky, j.r.bowersox@uky.edu \\ John B. Hickman \\ University of Kentucky, john.hickman@uky.edu
}

Follow this and additional works at: https://uknowledge.uky.edu/ees_facpub

Part of the Geology Commons

Right click to open a feedback form in a new tab to let us know how this document benefits you.

\section{Repository Citation}

Moecher, David P.; Bowersox, J. Richard; and Hickman, John B., "Zircon U-Pb Geochronology of Two Basement Cores (Kentucky, USA): Implications for Late Mesoproterozoic Sedimentation and Tectonics in the Eastern Midcontinent" (2018). Earth and Environmental Sciences Faculty Publications. 19. https://uknowledge.uky.edu/ees_facpub/19

This Article is brought to you for free and open access by the Earth and Environmental Sciences at UKnowledge. It has been accepted for inclusion in Earth and Environmental Sciences Faculty Publications by an authorized administrator of UKnowledge. For more information, please contact UKnowledge@lsv.uky.edu. 


\section{Zircon U-Pb Geochronology of Two Basement Cores (Kentucky, USA):}

Implications for Late Mesoproterozoic Sedimentation and Tectonics in the Eastern Midcontinent

Digital Object Identifier (DOI)

https://doi.org/10.1086/694825

\section{Notes/Citation Information}

Published in The Journal of Geology, v. 126, no. 1.

() 2017 by The University of Chicago. All rights reserved.

The copyright holder has granted the permission for posting the article here. 


\title{
Zircon U-Pb Geochronology of Two Basement Cores (Kentucky, USA): Implications for Late Mesoproterozoic Sedimentation and Tectonics in the Eastern Midcontinent
}

\author{
D. P. Moecher, ${ }^{1, *}$ J. R. Bowersox, ${ }^{2}$ and J. B. Hickman ${ }^{2}$ \\ 1. Department of Earth and Environmental Sciences, University of Kentucky, Lexington, Kentucky 40506, USA; \\ 2. Kentucky Geological Survey, University of Kentucky, Lexington, Kentucky 40506, USA
}

\begin{abstract}
A B S T R A C T
Basement cores from two wells drilled west and east of the Grenville front consist of feldspathic litharenite and granitic orthogneiss, respectively. Detrital zircon U-Pb ages for the litharenite define a broad dominant U-Pb age mode at ca. $1115 \mathrm{Ma}$. The dominant mode matches that for the type locality of the Middle Run Formation in the Ohio subsurface and is interpreted to consist of detrital zircons sourced from East Continent Rift volcanic sources (ca. $1100 \mathrm{Ma}$ ) and Grenville Shawinigan granites/gneisses (1120-1180 Ma). The youngest detrital zircon ages (ca. 1020 Ma) require a maximum depositional age that is at least 70 My younger than the time of Midcontinent and East Continent rifting and magmatism. We propose that the litharenite is correlative with the Middle Run Formation in Ohio and was deposited in an evolving late Grenville rift/foreland basin adjacent to the exhuming Grenville orogen. Zircon U-Pb secondary-ion mass spectrometry ages from orthogneiss define a discordant array with intercepts of ca. 1500 and $1000 \mathrm{Ma}$. The oldest concordant dates (ca. $1450 \mathrm{Ma}$, from oscillatory-zoned cores) are interpreted as the crystallization age of the igneous protolith of the orthogneiss. Metamorphic zircon rims define a weighted mean U-Pb age of $1018 \pm 19 \mathrm{Ma}(2 \sigma) \mathrm{Ma}$, interpreted to represent the time of high-grade metamorphism during the late Ottawan phase of the Grenville orogeny. This age pattern matches that of exposed basement in the Central Gneiss Belt of the Grenville Province (Ontario) and similar basement orthogneisses in Ohio and Kentucky that are interpreted to be of Eastern Granite-Rhyolite Province affinity. All age data are consistent with a provenance model of an actively exhuming Grenville orogen at ca. $1000 \mathrm{Ma}$ producing sediment that is mixing with recycled East Continent Rift sediments.
\end{abstract}

Online enhancements: supplemental tables.

\section{Introduction}

The nature of the basement beneath Paleozoic cover strata in the US midcontinent region has long intrigued geologists. Interest has focused on two questions: (1) the extent of crystalline rocks of the late Mesoproterozoic Grenville Province versus the middle Mesoproterozoic Granite-Rhyolite Province (Bass 1960; Lidiak et al. 1966; Hoppe et al. 1983; Van Schmus et al. 1996) and (2) the extent of late Mesoproterozoic continental rift basins (Keller et al. 1983; Stein et al. 2015). This interest was renewed when the Ohio Department of Natural Resources Division of Geological Survey well \#2627 (figs. 1, 2) penetrated a thick ( 1800-ft [ 549-m]) sequence of unfossilerous, arkosic, and lithic arenite

Manuscript received February 17, 2017; accepted September 5, 2017; electronically published December 15, 2017.

* Author for correspondence; e-mail: moker@uky.edu. designated as the Middle Run Formation, unconformably overlain by the basal middle Cambrian Mount Simon sandstone and thus requiring a Precambrian age for the Middle Run (Shrake 1991; Wickstrom et al. 1992). This discovery led to reexamination of regional basement samples and structure and definition of the "East Continent Rift Basin," the presumed extent of which is shown in figure 1. Subsequent detrital zircon $\mathrm{U}-\mathrm{Pb}$ geochronology of sandstone from the Middle Run Formation core yielded ca. $1.05 \mathrm{Ga}$ ages that require the Middle Run Formation in Ohio to be younger than Midcontinent-aged rifting and magmatism and more consistent with deposition in a Grenville foreland basin (Santos et al. 2002).

Studies of basement samples also precisely delineated the position of the "Grenville Front" (figs. 1, 2), 


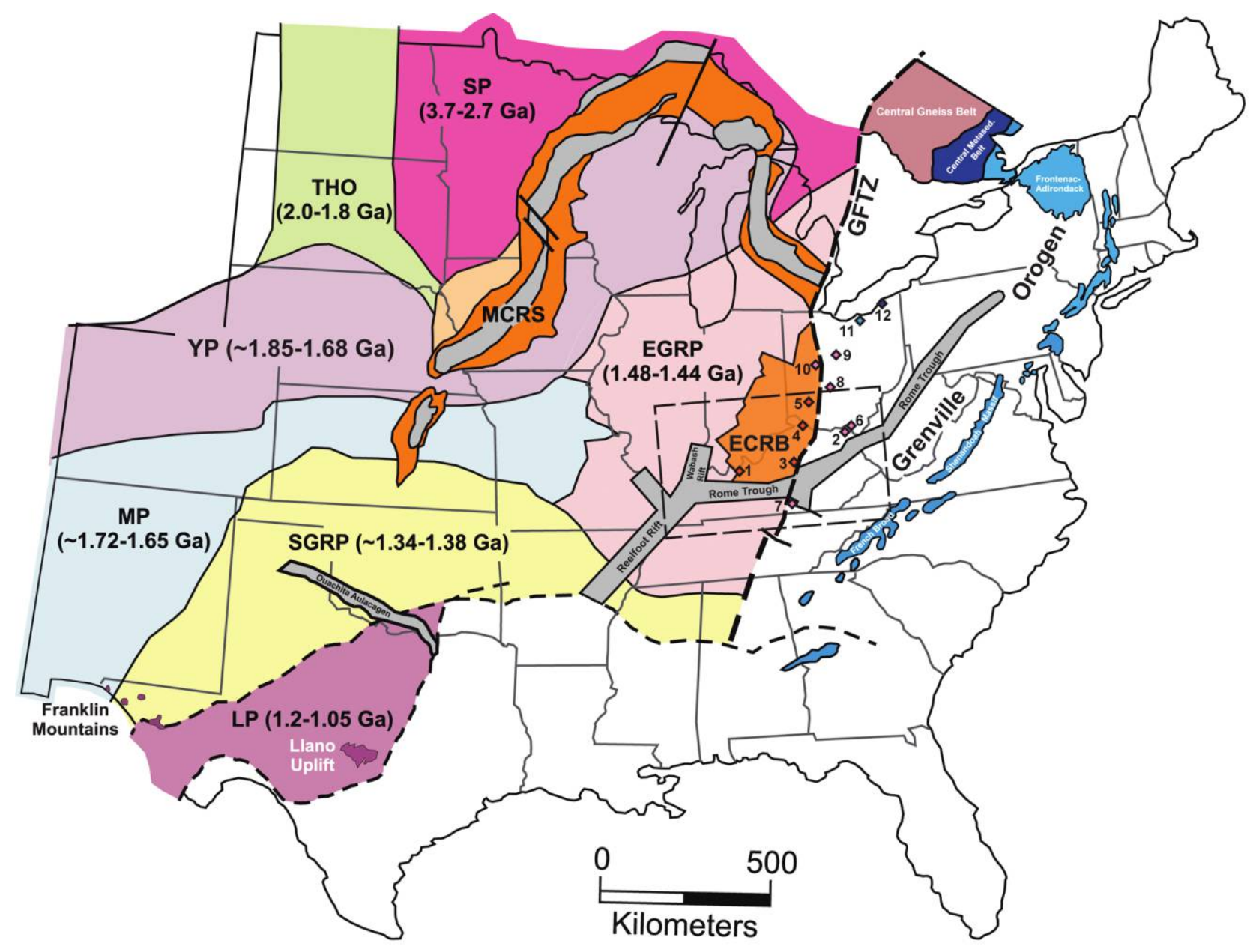

Figure 1. Generalized inferred Precambrian basement geology of the midcontinent region, showing the tectonic elements and Precambrian basement age provinces relevant to this study (after Wickstrom et al. 1992; Baranoski et al. 2009; Bickford et al. 2015), based primarily on drill core observations, and potential field geophysics west of the Grenville Front tectonic zone (GFTZ). The dashed box shows the location of figure 2. Basement drill core samples discussed in text are shown as diamonds and color-coded to reflect basement age province or affinity: (1) Hancock County, Kentucky, Marvin Blan \#1 (this study); (2) Carter County, Kentucky, Hanson Aggregates \#1 (this study); (3) Jessamine County, Kentucky, Texaco Sherrer \#1; (4) Campbell County, Kentucky, Ashland Wilson \#1; (5) Ohio Department of Natural Resources \#2627 (Middle Run discovery well); (6) USS Chemicals/US Steel \#1; (7) Pulaski County, Kentucky; (8): Fayette County, Ohio; (9) Morrow County, Ohio; (10) Logan County, Ohio; (11) Erie County, Ohio; 12: Lake County, Ohio. ECRB = East Continent Rift Basin; EGRP = Eastern Granite-Rhyolite Province; LP = Llano Province; MCRS = Midcontinent Rift system; MP = Mazatzal Province; SGRP = Southern Granite-Rhyolite Province; $\mathrm{SP}=$ Superior Province THO = Trans-Hudson orogen; YP = Yavapai Province.

the western extent of crust generated or metamorphosed during the Grenville orogenic cycle (ca. 1.350.95 Ga; McLelland and Daly 1996; Rivers 1997, 2008: Hynes and Rivers 2010; McClelland et al. 2013). Potential-field geophysics and drill cores/cuttings also confirmed the presence of gabbro, continental flood basalts, felsic volcanics, and volcanic to feldspathic lithic arenites in the subsurface of the Indiana-Ohio-Kentucky region west of the Grenville Front, and interpretation of seismic-reflection data permitted definition of a middle to deep crustal rift structure. The cumulative evidence led to the interpretation that the East Continent Rift Basin is a south- and eastward continuation of the Keweenawan Midcontinent Rift system (Wickstrom et al. 1992; fig. 1), of presumably the same age ( 1095-1105 Ma: Vervoort et al. 2007), that was overridden by crystalline thrust sheets of Mesoproterozoic crust in the final phases of Grenville collision (Rigolet phase, ca. 1010-980 Ma; Krogh 1994; Rivers 2008). Although the alternative interpretation of the seismic reflection data proposed that the Middle Run Formation 


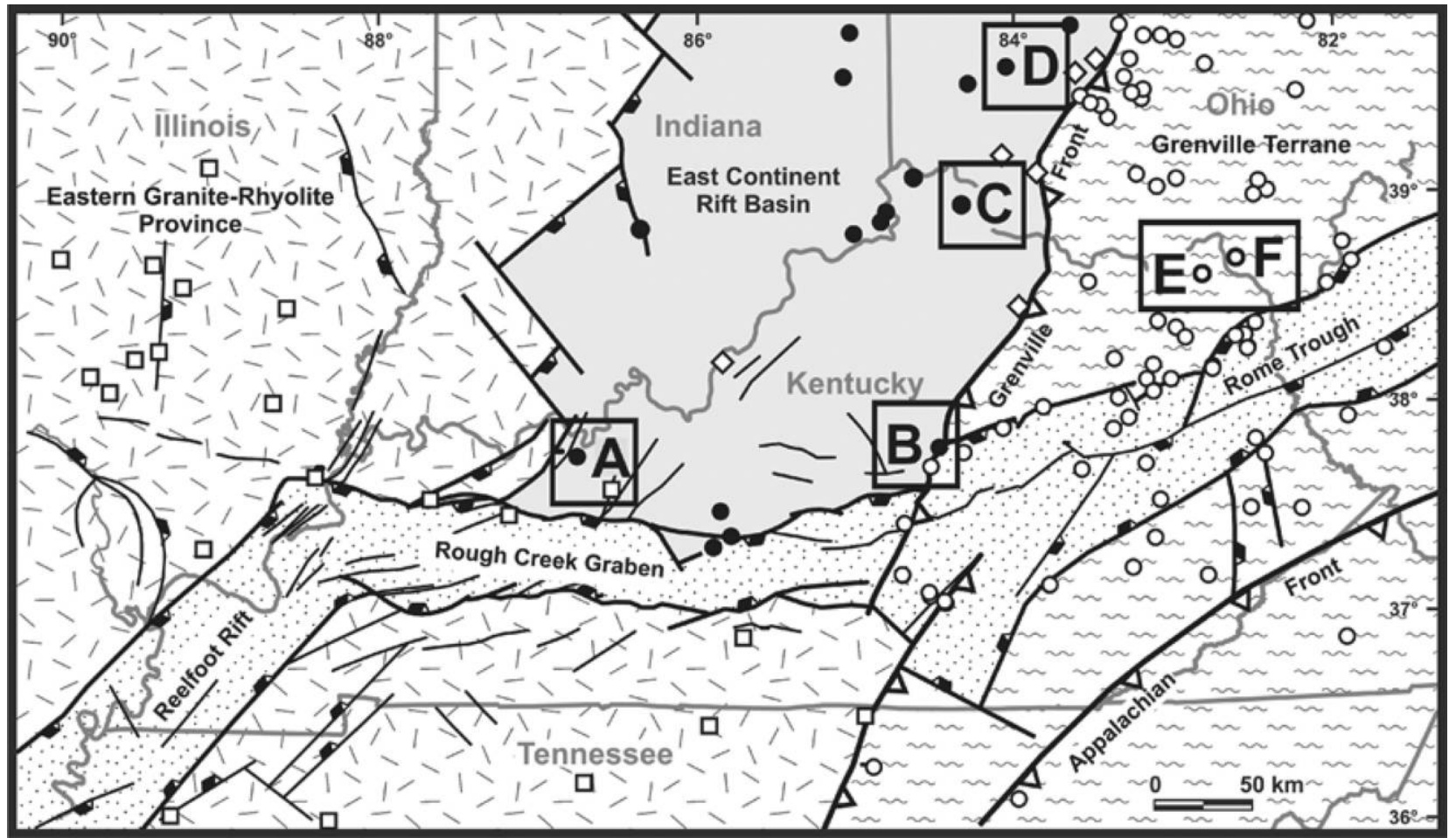

Figure 2. Generalized inferred basement geology of Kentucky (sub-Sauk unconformity) and adjacent states (after Drahovzal 1997; Stark 1997; Baranoski et al. 2009; Hickman 2011), showing location of relevant boreholes: (A) Kentucky Geological Survey \#1 Marvin Blan well, Hancock County, Kentucky, which recovered the core interpreted as Middle Run Formation (Bowersox and Williams 2014) analyzed for this study; (B) Texaco Sherrer \#1 well, Jessamine County, Kentucky, which penetrated a volcanic lithic arenite red bed sequence and overlying basalt; (C) Ashland Wilson \#1 well, Campbell County, Kentucky, which penetrated inferred lithic arenite red beds and thin ( 10-m) overlying basalt flows; (D) Ohio Department of Natural Resources, Division of Geological Survey \#2627 well, Warren County, Ohio, which recovered a core of the type Middle Run Formation lithic arenite and was analyzed for detrital zircon by Santos et al. (2002); (E) Kentucky Geological Survey \#1 Hanson Aggregates well, Carter County, Kentucky, which recovered a core of felsic orthogneiss analyzed for this study; (F) USS Chemicals/US Steel \#1 well, Scioto County, Ohio, which retrieved a core of basement orthogneiss containing zircon analyzed via SHRIMP U-Pb geochronology (Petersson et al. 2015). Filled circles represent wells penetrating arenites interpreted to be Middle Run Formation equivalents (Bowersox and Williams 2014), open circles wells penetrating Grenville terrane lithologies, open squares wells penetrating lithologies of the Eastern Granite-Rhyolite Province terrane, and open diamonds wells penetrating Precambrian mafic igneous rocks below the middle Cambrian unconformity. These latter four types of basement lithologies and terranes were interpreted from well cuttings.

in Ohio and Precambrian red beds in Kentucky were deposited in a synorogenic Grenville foreland basin (Baranoski et al. 2009), the inferred correlation remains to be tested via detrital zircon U-Pb geochronology and sandstone petrology.

We report here high-spatial-resolution detrital zircon U-Pb geochronology for possible Middle Run Formation equivalents west of the Grenville Front analyzed via laser ablation inductively coupled plasma mass spectrometry (LA-ICP-MS). Also presented are high-spatial-resolution secondary-ion mass spectrometry (SIMS) U-Pb zircon ages for basement orthogneiss east of the Grenville Front that also has recently identified correlatives in southern Ohio (Petersson et al. 2015). The geochronology provides new insight into the age of Precambrian basement in the eastern midcontinent; the presence, age, and provenance of potential foreland basin sediments; and potential tectonic scenarios for the late Mesoproterozoic history of central Laurentia that propose alternative models for the collisional and rift history of this region (Wickstrom et al. 1992; Hauser 1993, 1996; Baranoski et al. 2009; Stein et al. 2015).

\section{Geologic Setting and Background}

The Kentucky Geological Survey drilled two deep research wells for evaluating $\mathrm{CO}_{2}$ storage capacity in 
Kentucky, one on each side of the projected location of the Grenville Front, which is mapped as running north-south under central Kentucky (Wickstrom et al. 1992; Bowersox and Williams 2014; figs. 1, 2). A core of layered granitic orthogneiss was recovered from the Kentucky Geological Survey \#1 Hanson Aggregates well, Carter County, Kentucky (fig. 2, location E), located $80 \mathrm{~km}$ east of the front. In contrast, a core of brick-red lithic and feldspathic arenite interpreted as correlative with the Middle Run Formation of Ohio (Bowersox and Williams 2014) was recovered from the Kentucky Geological Survey \#1 Marvin Blan well, Hancock County, Kentucky (fig. 2, location A), located $185 \mathrm{~km}$ west of the front and $125 \mathrm{~m}$ below the middle Cambrian unconformity. The western Kentucky litharenite was interpreted to be either rift basin fill associated with the East Continent Rift Basin or Grenville orogen foreland basin fill (Bowersox and Williams 2014). In addition to the type section of the Middle Run Formation in Ohio, Precambrian red bed sequences interpreted as Middle Run Formation were previously found in two wells in central Kentucky, allowing comparisons with other samples interpreted as Middle Run Formation (Wickstrom et al. 1992). The Texaco Sherrer \#1 well (Jessamine County, KY; fig. 2, location B) penetrated a thick red bed sequence (interpreted from geophysical well logs and two-dimensional reflection seismic data as $\sim 830 \mathrm{~m}$ thick) overlain by $156 \mathrm{~m}$ of basalt of uncertain age, which is in turn overlain by the middle Cambrian Conasauga Group. The red bed unit in the Sherrer well, which may or may not be a Middle Run Formation correlative /discussed further below), includes conglomerates with felsic and mafic volcanic clasts and coarse-grained sandstones with definitive felsic volcanic lithic fragments, all capped by $155 \mathrm{~m}$ of basalt. The Ashland Wilson \#1 well (Campbell County, KY; fig. 2, location C) penetrated a very thin Middle Run Formation-like sandstone $(\sim 20 \mathrm{~m})$ sandwiched between two basalt flows of uncertain age, the upper one of which is overlain by middle Cambrian strata. These basalts are of continental affinity on the basis of chemistry and were assumed to be broadly correlative with basaltic volcanism of the Midcontinent Rift system (Wickstrom et al. 1992), although no modern geochronology exists to test this assumption. No basalt is present capping either the Middle Run in Ohio or the lithic arenite in western Kentucky.

In addition to the minimum-age constraint from the youngest detrital zircons, the minimum depositional age for the Middle Run Formation at the type locality is constrained by the timing of thrusting along the Grenville Front. There exists a con- sensus that the Middle Run sequence is overthrust by Grenville basement in the subsurface of Ohio (Wickstrom et al. 1992; Baranoski et al. 2009). Krogh (1994) bracketed the time of thrusting to be 995-980 Ma and "essentially coeval" along the ca. 2000-km exposed length of the Grenville Front in Canada. If it is assumed that this timing is relevant in the US midcontinent, then the Middle Run Formation nearest the Grenville Front in Ohio is no younger than $995-980 \mathrm{Ma}$.

In addition to the inferred Mesoproterozoic East Continent Rift system, the Precambrian basement of Kentucky is cut by the lower Cambrian Rough Creek and Rome Trough graben system (fig. 2; Hickman 2011). This system produced numerous basement faults with demonstrable offset of the Precambrian basement, likely adding a degree of complexity to the simplified basement map shown in figure 1. It is therefore possible that not all "red bed" sequences in the midcontinent subsurface are the same age.

\section{Sample Description}

A 10-m-thick sample of brick-red, densely packed, fine-grained, feldspathic litharenite (fig. 3A) was recovered in a core from the Kentucky Geological Survey Marvin Blan \#1 well (Hancock County, KY; figs. 1, 2) at depths of 2438-2448 m (125 m below the Cambrian unconformity). Subangular quartz and feldspar (albitic plagioclase, microcline, perthite) constitute $\sim 50 \%$ of the grains (fig. $3 C$ ). Lithic grains consist of very fine-grained material and are difficult to identify via optical petrography. Demonstrable pristine volcanic lithic fragments are notably absent in the Blan \#1 litharenite, in contrast to their purported presence in the Middle Run Formation from the type locality (Shrake 1991; Wickstrom et al. 1992) and their documented presence in the central Kentucky Sherrer \#1 well (fig. 3J, $3 K)$.

Scanning electron microscopy (SEM) and energydispersive spectrometry were used to identify mineralogic components of the various fine-grained lithic fragments and of other detrital mineral grains in the western Kentucky litharenite (fig. 3C-3E). The foliated phyllite (chlorite-rich) and sericite-rich lithic grains (fig. 3F) cannot be altered felsic volcanic rock fragments, as the latter are not sufficiently aluminous to yield a low-grade metamorphic mineral assemblage of chlorite + white mica. Aside from zircon, the detrital heavy-mineral assemblage in the litharenite is dominated by titaniferous magnetite, with lesser tourmaline, titanite, apatite, rutile, biotite, and chlorite (fig. 3G-3I). 

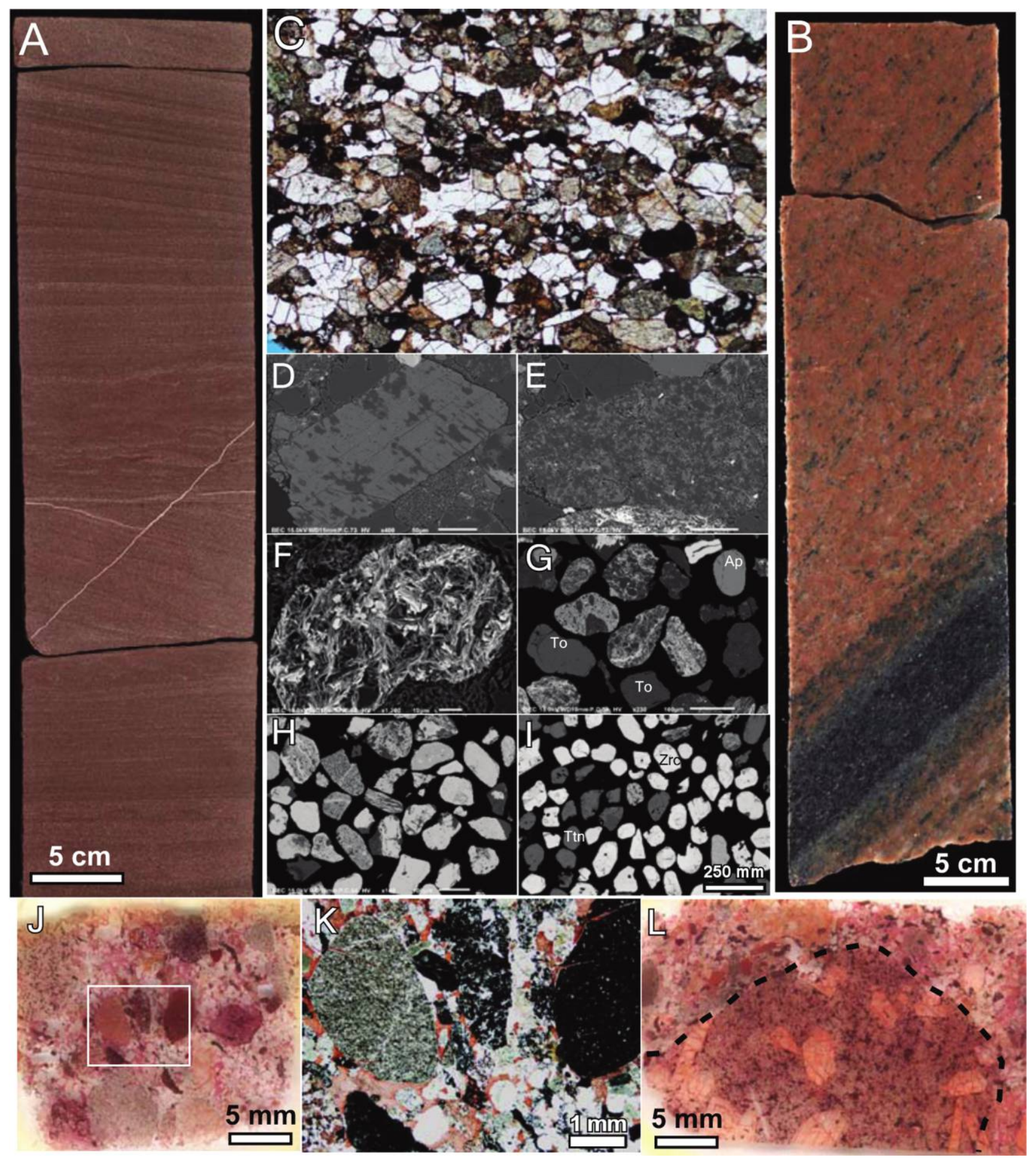

Figure 3. $A, B$, Photographs of laminated feldspathic litharenite and banded basement orthogneiss, respectively. $C$, Thin-section photomicrograph of Middle Run Formation. Clear angular grains are quartz, and cloudy translucent grains are feldspar. Note rounded (detrital) opaque grains and numerous very fine-grained lithic grains (see $F$ ). $D$, Backscattered electron image of perthitic alkali feldspar clast in feldspathic lithic arenite (light gray $=\mathrm{K}$-feldspar; dark gray $=$ albite). $E$, Fine-grained K-feldspar-albite intergrowth that is a potential volcanic lithic fragment (grayscale as in D). F, Detrital chlorite-muscovite phyllite lithic clast. $G$, Detrital tourmaline (To) and apatite (Ap) in heavymineral fraction. Other detrital grains are fine-grained intergrowths of iron oxide and silicates. $H$, Magnetic mineral concentrate from heavy-mineral fraction. Solid grains are titaniferous magnetite. Other grains consist of magnetite intergrown with silicates. I, Detrital zircon grain mount used for U-Pb geochronology, showing high proportion of titanite in the heavy-mineral fraction. J, Thin section of core from Texaco Sherrer \#1 well showing volcanic clasts. $K$, Photomicrograph of area outlined in white in $J . L$, Rhyolite clast (dashed outline) with K-feldspar phenocrysts in thin section of Sherrer \#1 well. 
A 5-m-thick sample of granitic orthogneiss was recovered from the Kentucky Geological Survey Hanson Aggregates \#1 well beneath the middle Cambrian unconformity at depths of 1438-1443 m. The orthogneiss consists of meter-thick bands of weakly foliated, medium-grained, equigranular, brick-red granitic gneiss interlayered with centimeter-thick bands of dark-gray amphibolite (fig. 3B). The granitic component was the material dated for this study. An identical lithology that occurs in a drill core from the USS Chemicals/US Steel \#1 well in southern Ohio, $32 \mathrm{~km}$ northeast of the Hanson \#1 well in Carter County, Kentucky (fig. 2, location F), was dated via SHRIMP $\mathrm{U}-\mathrm{Pb}$ zircon geochronology and is interpreted to have a ca. 1450 Ma protolith crystallization age and a ca. 1000 Ma metamorphic age component (Petersson et al. 2015).

\section{Methods}

Samples of each core $(\sim 0.5 \mathrm{~kg})$ were crushed, ground to sand size, wet-sieved to 250-150- and 125-50- $\mu \mathrm{m}$ size fractions, and run through acetylene tetrabromide (specific gravity $[S G]=2.8$ ) and methylene iodide $(\mathrm{SG}=3.2$ ) to concentrate the heavy minerals. A hand magnet was used to remove abundant detrital magnetite, and a magnetic separator at low currents $(0.25-0.50 \mathrm{~A})$ was used to remove mafic minerals to produce a zircon concentrate. Two different samples of litharenite from the Marvin Blan \#1 well were processed separately. Zircon grains from one sample (MR1) of litharenite and the orthogneiss were handpicked for mounting, whereas bulk grains from the second sample (MR2) of litharenite were poured into 1-inch (25.4-mm) epoxy molds, sanded, and polished to expose approximate grain cores. Backscattered electron and cathodoluminscence $(\mathrm{CL})$ imaging for locating the beam were conducted on the CAMECA SX50 electron probe microanalyzer and the JEOL IT-100 SEM at the University of Kentucky. Representative CL images of zircon zoning patterns in both samples are shown in figure 4.

LA-ICP-MS. Detrital zircon U-Pb geochronology via LA-ICP-MS was conducted in two sessions on two different hand samples of the Blan \#1 litharenite at the University of Arizona Laserchron facility, following the analysis and data reduction methods of Gehrels et al. (2008). Zircon U-Pb standards were FC1 (accepted age of $1099 \pm 1 \mathrm{Ma}$; same as AS3, below), SL Mix (564 $\pm 2 \mathrm{Ma}$ ), and R33 (419 \pm $2 \mathrm{Ma}$; all ages $2 \sigma$. Repeated analysis of the standards during the analytical sessions yielded highly concordant analyses $(100 \% \pm 2 \%)$ and weighted mean ${ }^{206} \mathrm{~Pb} /{ }^{207} \mathrm{~Pb}$ ages of $1099 \pm 7,557 \pm 5$, and $417 \pm 6 \mathrm{Ma}$ (all $2 \sigma$ ), respectively. Isotopic ratios and calculated age data are compiled in table S1; tables S1 and S2 are available online. Isoplot, version 4.1 (Ludwig 2008), was used to construct $\mathrm{U}-\mathrm{Pb}$ concordia diagrams and probability age distribution plots. Data for detrital zircon grains used to construct the age histograms are only those ${ }^{206} \mathrm{~Pb} /{ }^{207} \mathrm{~Pb}$ ages that were $100 \% \pm 5 \%$ concordant, which plot within $1 \sigma$ error on concordia diagrams. Age histograms with probability age distributions and Tera-Wasserburg diagram showing degree of concordance for all Proterozoic grains are presented in figure $6 \mathrm{~A}$.

SIMS. Zircon U-Pb SIMS analysis was conducted at the UCLA Keck facility on the CAMECA ims1270 ion microprobe in single-collector mode. Details of the analytical methods are presented in Schmitt et al. (2003). The zircon standard was AS3 (1099 Ma $\pm 1 \mathrm{Ma}, 2$ \%: Paces and Miller 1993; Schmitz et al. 2003). The raw isotope peak intensities were processed with the UCLA in-house software program ZIPS to obtain standard-corrected isotope ratios. Standard analyses during the analytical session were $100 \% \pm 3 \%$ concordant. The weighted mean ${ }^{207} \mathrm{~Pb} /{ }^{206} \mathrm{~Pb}$ age for AS3 measured during the SIMS session was $1099 \pm 4 \mathrm{Ma}(2 \sigma)$. Results are compiled in table S2 and presented on a TeraWasserburg concordia diagram (fig. 5).

\section{Results}

Litharenite. The high proportion of detrital feldspar grains in the western Kentucky litharenite is consistent with a felsic plutonic or orthogneissic component in the source terrane. The diverse heavymineral assemblage dominated by rounded detrital grains of magnetite-ulvospinel, titanite, tourmaline, apatite, and rutile (fig. 3G-3I) is also consistent with either a metamorphic or a felsic plutonic component in the source but not with a dominantly felsic volcanic source. The lack of both demonstrably volcanic lithic clasts and a high proportion of phyllitic and cryptocrystalline lithic fragments is surprising, considering that felsic volcanic and epizonal granites constitute most of the basement in the region and that the Sherrer \#1 well in central Kentucky contains abundant demonstrable volcanic lithic clasts (fig. 3J-3L).

Detrital zircon grains exhibit a range of grain shapes and CL zoning patterns (fig. 4). Many of the grains are euhedral and prismatic, with oscillatory zoning, consistent with an ultimate magmatic origin and minor abrasion during transport. Grains that have rounded shapes that truncate oscillatory zoning bands are mostly likely magmatic grains 

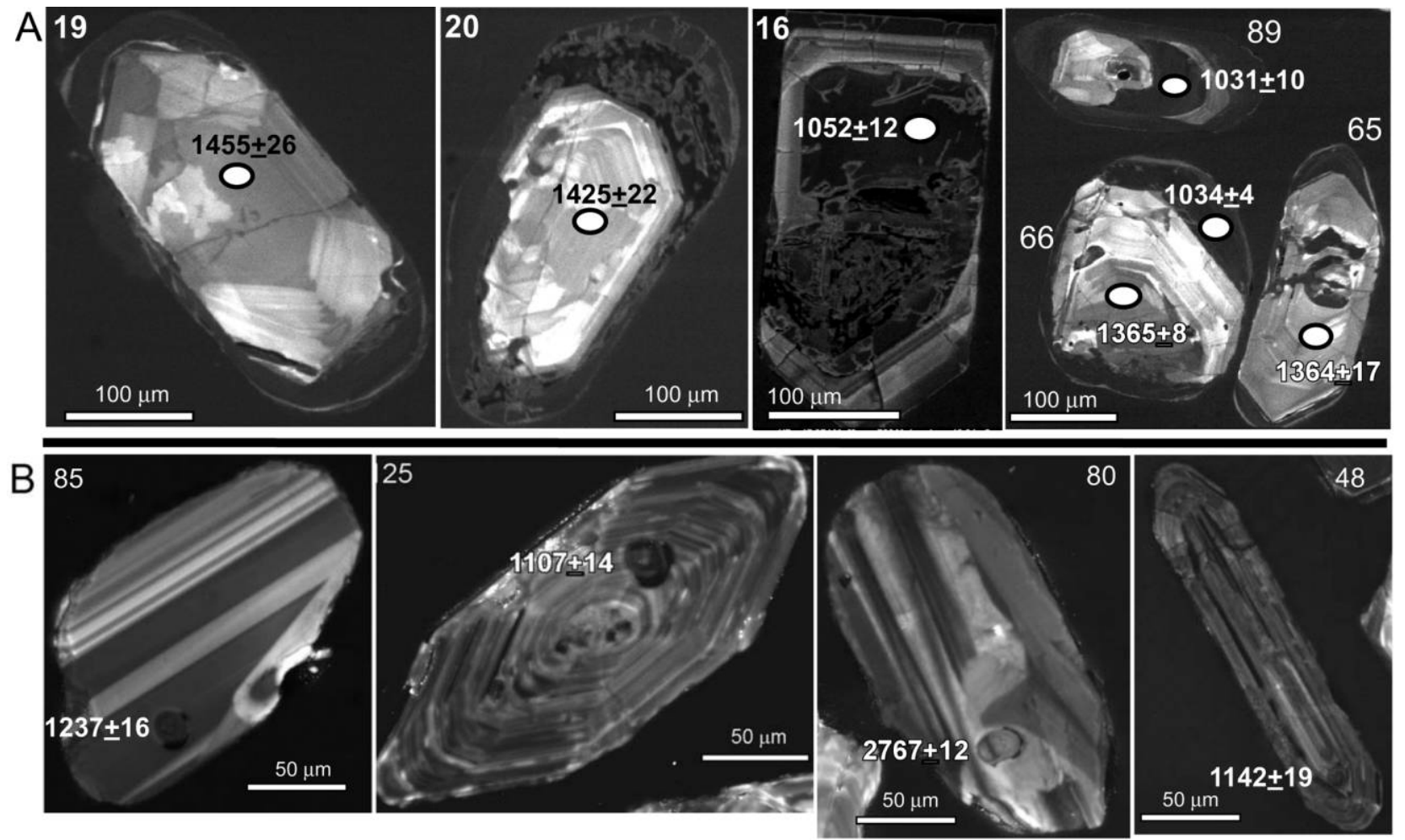

Figure 4. A, Representative cathodoluminescence (CL) images of zircon grains from orthogneiss, with analysis numbers, spots, and ages (corresponding to analyses in table S2, available online), illustrating the three generations of zircon growth: bright oscillatory-zoned and variably embayed cores (grains 19, 20, 66, 65, and 89); a dark-gray, unzoned generation that may constitute cores (grain 16) or overgrow oscillatory-zoned cores (grains 19, 20, 65, 66, and 89); and a thin, euhedral, oscillatory-zoned rim that overgrows and mimics the shape of the host grain (grain 16). $B$, Representative CL images of detrital zircon grains from the Middle Run Formation, with analysis spots, numbers, and ages (corresponding to analyses for MR\#1 in table S1, available online). Grains 85 and 80 are more highly abraded, and grains 25 and 48 are more euhedral and oscillatory zoned, consistent with a magmatic origin.

that experienced a sufficiently long transport history to be abraded. Detrital zircon U-Pb ages are generally concordant (most are 97\%-103\% concordant, averaging $100 \% \pm 3 \%$ ), consistent with a lack of significant $\mathrm{Pb}$ loss from postcrystallization disturbance by metamorphism or recrystallization (table S2; fig. $5 \mathrm{~A}$ inset). Age precision for most grains is $1 \%-2 \%$ on an absolute-age basis (table $S 1$ ).

The results of detrital zircon U-Pb geochronology for both samples of the litharenite (MR1 and MR2; table S1) were combined into a single histogram of 356 analyses that are $95 \%-105 \%$ concordant and have $1 \%-2 \%$ absolute-age precision (10-20 Ma). The dominant age mode is a broad peak at ca. $1115 \mathrm{Ma}$ (slightly skewed to older ages) defined by ages ranging from ca. 1080 to $1180 \mathrm{Ma}$ (fig. 5A). Other age modes are ca. 1230, 1460, 1330, 1380, and $1640 \mathrm{Ma}$ (in decreasing amplitude; fig. 5A). There are a few individual grains with ages between 1700 and $1900 \mathrm{Ma}$. The oldest ages are for three late Archean grains (table S1; not shown on histogram).
The three youngest detrital zircon grains have ${ }^{207} \mathrm{~Pb} /$ ${ }^{206} \mathrm{~Pb}$ crystallization ages of $1017 \pm 24,1023 \pm 11$, and $1031 \pm 44 \mathrm{Ma}$.

Shown for comparison (fig. 5A) is the detrital zircon U-Pb probability density plot curve for the type section of the Middle Run Formation from the Warren County, Ohio, well (SHRIMP ${ }^{206} \mathrm{~Pb} /{ }^{207} \mathrm{~Pb}$ ages; grains with $\pm 5 \%$ discordance or less; Santos et al. 2002). These SHRIMP ages have very low precision $( \pm 10 \%$ absolute; table 2 of Santos et al. 2002), precluding resolution of minor age modes, as indicated by the broad dominant peak in the probability age distribution curve (fig. 5A). However, the dominant age mode is at $\sim 110 \mathrm{Ma}$ and skewed to older ages, similar to the western Kentucky litharenite. This age correspondence supports the tentative correlation of the western Kentucky litharenite with the Middle Run Formation in Ohio based on lithology and stratigraphic position beneath the basal Cambrian (Bowersox and Williams 2014). 

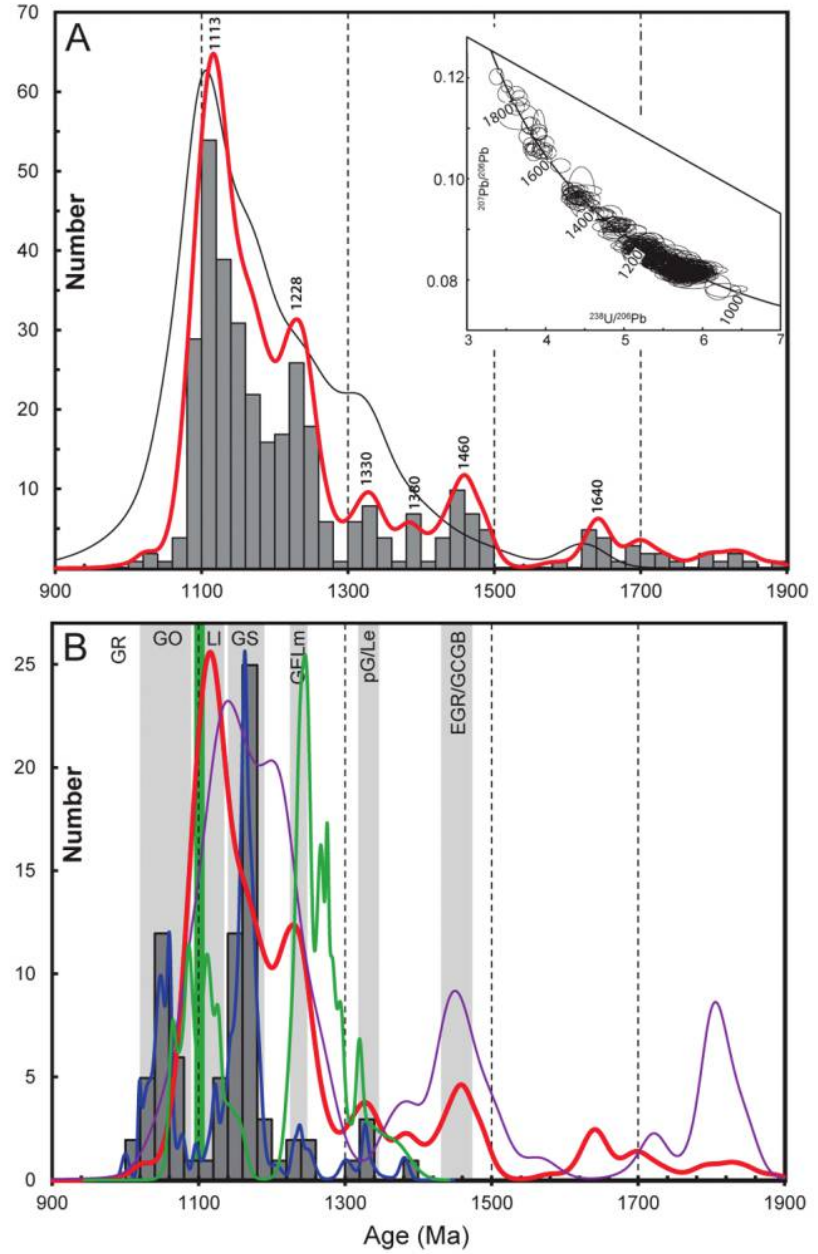

Figure 5. $A$, Histogram $\left({ }^{207} \mathrm{~Pb} /{ }^{206} \mathrm{~Pb}\right.$ ages $)$ and probability density function (PDF; red line) for all detrital zircon ages (95\%-105\% concordant) from the lithic arenite ( $n=353$; Archean-aged grains were omitted to allow expansion of timescale). Inset, U-Pb Tera-Wasserburg concordia diagram showing general degree of concordance of all analyzed Proterozoic-aged grains. The thin black line represents the PDF for detrital zircon in the Middle Run Formation from the type locality in Ohio (Santos et al. 2002). The low age precision for these grains ( 20-140 Ma: table 1 of Santos et al. 2002) precludes resolution of distinct age modes. However, the greatest number of grains is in the 1060-1140 Ma range, in general agreement with the ages obtained in this study. B, Histogram of concordant zircon U-Pb SHRIMP ages $\left({ }^{207} \mathrm{~Pb} /{ }^{206} \mathrm{~Pb}\right)$ from Grenville granitoid rocks in eastern Laurentian basement massifs and the Adirondacks (Southworth et al. 2010; Tollo et al. 2010; McLelland et al. 2013) that define the "Grenville age doublet" and are interpreted to represent crystallization ages for the host pluton. These ages have much higher precision $(1 \sigma=4-10 \mathrm{Ma})$ than the detrital zircon ages, resulting in more precise age modes and narrower age peaks on the PDF (blue line). The red line represents the PDF for the Middle Run Formation of this study (from $A$ ). The green band represents the time span of Midcontinent rift
Also shown for comparison are SHRIMP zircon $\mathrm{U}-\mathrm{Pb}$ ages of Grenvillian granites from Appalachian basement massifs (Southworth et al. 2010) and the Adirondacks (McLelland et al. 2013; fig. 5B). These are higher-precision SHRIMP ages and define the two major periods of Grenville magmatism and metamorphism in eastern Laurentia: the Ottawan, at ca. 1040-1080 Ma, and the Shawinigan, at ca. 1140$1180 \mathrm{Ma}$ (McLelland and Daly 1996; Rivers 1997; McLelland et al. 2013). Ages of metamorphic zircon in Appalachian basement massifs conform to this pattern (Southworth et al. 2010). Figure 5B highlights the distinction between the eastern Laurentian Grenville age modes and the dominant age mode of the western Kentucky and Ohio Middle Run Formation, which is positioned between the two dominant Grenville peaks.

Robust maxima on depositional ages for sedimentary strata may be obtained from the youngest detrital zircon ages if there exists a population of grains whose ages are the same within analytical precision and distinct from other age populations. Using the "youngest $1 \sigma$ grain cluster $(n \geq 2)$ " criterion of Dickinson and Gehrels (2009), the ages of the three youngest grains in the Kentucky litharenite (see above) yield a maximum depositional age of ca. $1020 \mathrm{Ma}$. The litharenite must have been deposited after this time, with an additional increment of time required to exhume the host granites that sourced the ca. $1020 \mathrm{Ma}$ detrital zircons in the Middle Run. This age corresponds to the late Ottawan phase of the Grenville orogeny and is consistent with the litharenite being a late synorogenic Grenville clastic deposit. This age is also ca. $70 \mathrm{My}$ younger than the time of Midcontinent rifting.

volcanism and plutonism. Gray bands represent time spans of late Mesoproterozoic magmatic events in eastern and southwestern Laurentia: GELm = Elzevirian orogeny and middle phase of Grenville events in Llano region; GO = Ottawan phase of Grenville orogeny; GR = Rigolet phase of Grenville orogeny; GS = Shawinigan orogeny; Ll = late Grenville magmatic events in Llano region; $\mathrm{pG} / \mathrm{Le}=$ preGrenville events in eastern Laurentia and early Grenville events in Llano region; EGR/GCGB = magmatic events in the Eastern Granite-Rhyolite Province of the US midcontinent region and the Central Gneiss Belt of the Grenville Province in Ontario. The green line represents the probability age distribution for zircon TIMS U-Pb ages from magmatic rocks in the southwestern Grenville Province in Texas (compiled in Mosher 1998). The purple line represents the probability age distribution for the late Mesoproterozoic Hazel Formation of west Texas, interpreted to be a Grenville foreland basin deposit (Spencer et al. 2014). 
Orthogneiss. Cathodoluminescence imaging reveals a sequential zircon growth history (fig. $4 A$ ). Most grains consist of relatively bright, oscillatoryand/or sector-zoned cores that are variably and deeply embayed, overgrown by an intermediate zone of relatively dark unzoned zircon of variable width, which is in turn overgrown by thin $(10$ $20-\mu \mathrm{m})$, dark, oscillatory-zoned rims. The secondmost-common grain type is euhedral, dark, and unzoned in CL with a thin oscillatory-zoned rim. The dark zone in both types of grains is commonly metamict (fig. 4). There are thus three discernible generations of zircon growth: (1) variably embayed oscillatory-zoned cores interpreted to result from magmatic crystallization (Corfu et al. 2003), (2) the dark, unzoned component interpreted to result from metamorphic recrystallization of precursor magmatic zircon, and (3) a second minor magmatic event that could be related to melting and leucosome formation. Only the first two generations were wide enough to accommodate the primary ion beam $(\sim 20 \mu \mathrm{m})$. The metamict zones were avoided in SIMS analysis.

Ages for the two dated generations of zircon confirm the interpretation of two growth events for the greatest volume of zircon in the orthogneiss. Most analyses plot along a discordant array between ca. 1500 and $1000 \mathrm{Ma}$ (fig. 6A), although some data spread along concordia through $\sim 1350$ to $\sim 1250 \mathrm{Ma}$. Oscillatory-zoned cores define the array of ages between ca. 1450 and $1250 \mathrm{Ma}$, and the dark zones define the younger set of ages that tend to cluster near $1000 \mathrm{Ma}$. The discordant ages falling along the chord and the concordant ages between 1450 and $1250 \mathrm{Ma}$ are typical of zircon from Precambrian rocks that have undergone $\mathrm{Pb}$ loss or recrystallization during high-temperature magmatic or metamorphic events (e.g., Chiarenzelli and McLelland 1993; Mezger and Krogstad 1997; Ashwal et al. 1999; Halpin et al. 2012; Whitehouse et al. 2014), with the dominant lead loss event in this sample occurring at ca. 1000 Ma. Following Halpin et al. (2012), we interpret the original magmatic crystallization age of the orthogneiss protolith to be ca. $1450 \pm 20 \mathrm{Ma}$, which corresponds to the age of the oldest concordant analysis (grain 19; fig. 4A). The weighted mean ${ }^{206} \mathrm{~Pb} /{ }^{207} \mathrm{~Pb}$ age for the dark zones is $1018 \pm 19 \mathrm{Ma}(2 \sigma$; fig. $6 B)$, which is interpreted to be the time of high-grade metamorphism of the orthogneiss protolith and the event that produced lead loss in the discordant grains. This age corresponds broadly to the late Ottawan phase of Grenville orogenesis for which plutonism and high-grade regional metamorphism have been widely identified in the Grenville Province of Can-
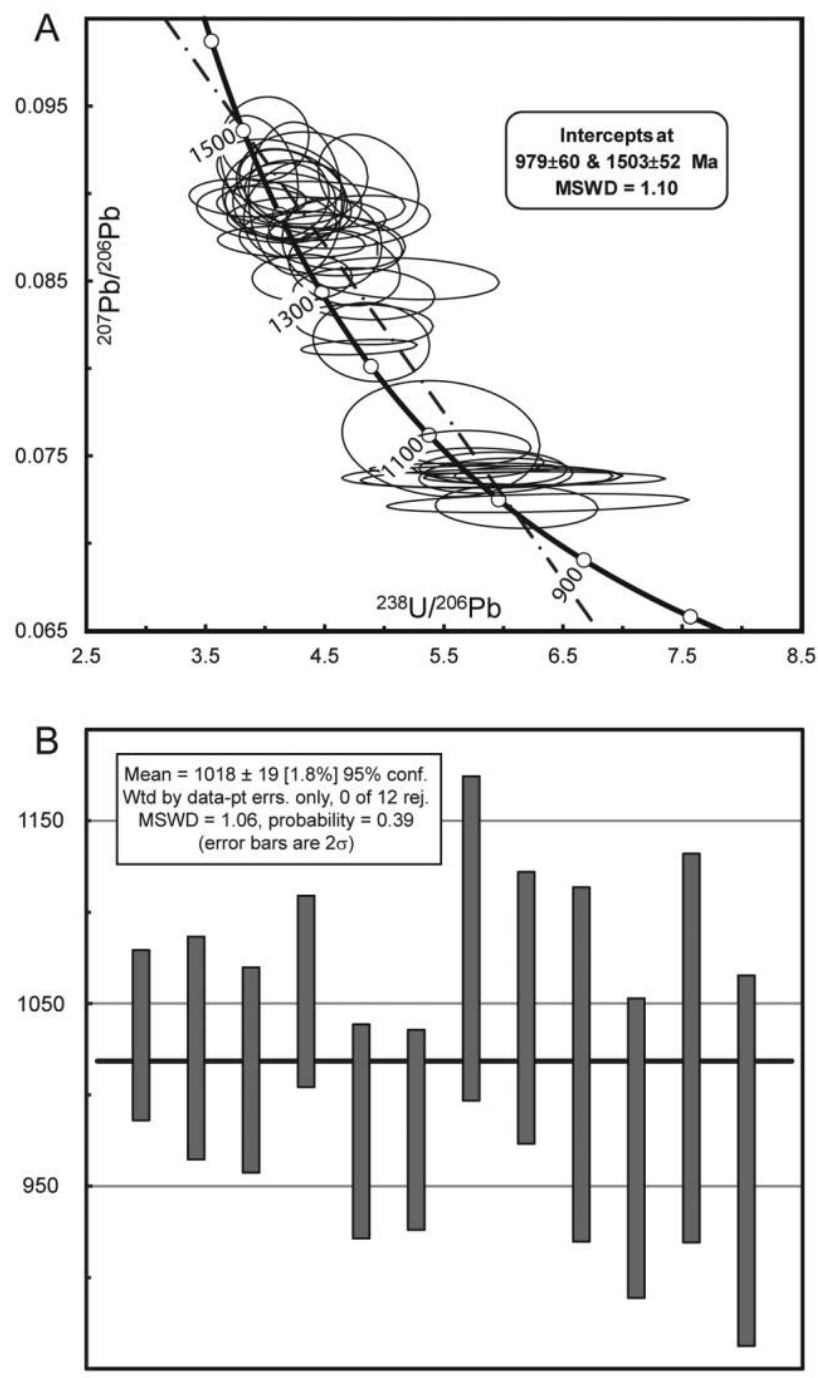

Figure 6. $A$, Tera-Wasserberg U-Pb concordia diagram for all zircon analyses from the granitic orthogneiss (two highly reversely discordant grains were omitted form the plot), with ages of upper and lower intercepts of discordia. $B$, Bar diagram showing calculated weighted mean age for the dark-gray generation of zircon that appears to define a coherent age population. A color version of this figure is available online.

ada and eastern Laurentia (Mezger et al. 1991; Rivers 1997, 2008; Carr et al. 2000; Southworth 2010; Tollo et al. 2010; McLelland et al. 2013; Johnson et al. 2017). The age is also similar to the maximum depositional age of the litharenite.

\section{Discussion}

Litharenite. Other than the dominant age mode (ca. 1080-1180 Ma), the various detrital zircon age modes in the western Kentucky litharenite can each 
be correlated with specific granitic magmatic or metamorphic events in known basement terranes in the eastern and midcontinent United States, supporting a generally east-central Laurentian provenance. These events include (1) the Grenville Elzevirian event in the Appalachians, Adirondacks, and Central Metasedimentary Belt (ca. $1230 \mathrm{Ma}$, the second-largest mode); (2) the Eastern GraniteRhyolite (EGR) Province east and west of the Grenville Front (ca. $1450 \mathrm{Ma}$ ); (3) the Southern GraniteRhyolite Province (1380 Ma); (4) pre-Grenvillian magmatic rocks of the Adirondacks and Appalachians (1330 Ma); and (5) the Mazatzal terrane (1640 Ma). Scattered grains of 1000-1050 Ma (Grenville Ottawan), 1700-1900 Ma (Yavapai and Penokean Provinces), and Archean (Superior Province) ages are insufficient in number to define age modes but have sources that must be accounted for in any provenance model. All these crustal age provinces could have supplied first-cycle detrital zircon or zircon grains recycled from East Continent Rift Basin sediments to the Middle Run basin at ca. $1000 \mathrm{Ma}$.

To a first approximation, the Kentucky and Ohio Middle Run detrital zircon age spectra, and particularly the dominant age mode, might be interpreted to represent a broadly "Grenvillian" provenance (e.g, Eriksson et al. 2004; Rainbird et al. 2012; Craddock et al. 2013; Yonkee et al. 2014). However, the two dominant Grenville granitic magma- and zircon-generating events (the ca. 1020-1070 Ottawan and the ca. 1140-1180 Ma Shawinigan; fig. 5B) are represented by a relatively limited number of ages that are either rare (former) or subdued (latter) in the western Kentucky litharenite age spectrum. Although the older ages included in the dominant litharenite age mode overlap the Shawinigan Grenville event (Rivers 1997, 2008; Carr et al. 2000; Southworth et al. 2010; McLelland et al. 2013; Aleinikoff and Walsh 2017; fig. 5B), there is not a resolvable major age mode at $1140-1180 \mathrm{Ma}$. More noteworthy is that, other than three single grains, the western litharenite spectrum lacks a major detrital zircon age mode at ca. 1040-1090 Ma characteristic of the Ottawan phase of the Grenville orogeny (Rivers 1997, 2008; Southworth et al. 2010; McLelland et al. 2013; fig. 5B). Thus, the western Kentucky litharenite age spectrum lacks the "Grenville age doublet" that is the fingerprint of the Grenville orogen in eastern Laurentia and that many consider the defining characteristic of eastern Grenville provenance (e.g., Eriksson et al. 2003, 2004; Thomas et al. 2004; Moecher and Samson 2006; Chakraborty et al. 2012). The Grenville doublet is also present in upper Neoproterozoic, basal Cambrian, Middle Ordovician, Devonian, and Car- boniferous detrital zircon age spectra for clastic rocks inferred to have a "Grenville source" in eastern Laurentia (e.g., Eriksson et al. 2004; Becker et al. 2005; Moecher and Samson 2006; Park et al. 2010; Chakraborty et al. 2012; Satkoski et al. 2012). However, these clastic sequences are all $\geq 400 \mathrm{My}$ younger than the Grenville events, so that Ottawan and Shawinigan granites and gneisses had been exhumed and were potential provenance sources by and after the late Neoproterozoic across Laurentia.

The lack of a major Ottawan age mode can be accounted for if rocks of Ottawan age are not yet exhumed and widely available to generate detrital zircon. Zircon U-Pb crystallization ages of Ottawan granites and garnet $\mathrm{U}-\mathrm{Pb}$ and Lu-Hf ages for peak Ottawan metamorphism in Ontario, the Adirondacks, and the Appalachians range from 1020 to $1070 \mathrm{Ma}$ (Mezger et al. 1991; Southworth et al. 2010; Johnson et al. 2017). Metamorphic cooling ages (hornblende, biotite, and muscovite ${ }^{40} \mathrm{Ar}^{-39} \mathrm{Ar}^{3}$ rutile, titanite, and monazite $\mathrm{U}-\mathrm{Pb}$ ) throughout Ontario, the Adirondacks, and Appalachian basement massifs are all ca. 1000-900 Ma (Cosca et al. 1991; Mezger et al. 1991; Dahl et al. 2004; S. Southworth, personal communication, 2017). These ages demonstrate that Ottawan-aged rocks generally resided at midcrustal depths when the litharenite was being deposited and were exhumed during slow uplift through the late Neoproterozoic (0.03$0.14 \mathrm{~km} \mathrm{My}^{-1}$ : Cosca et al. 1991). A major Ottawan Grenville detrital zircon age mode would therefore not be expected in a ca. $1000 \mathrm{Ma}$ Grenville foreland sequence and would be impossible in ca. 1100 Midcontinent or East Continent Rift basin sediments.

In this regard the paucity of Ottawan-aged detrital zircon in syn-Ottawan sediments reflects the "one orogeny behind" principle (Thomas et al. 2004; Thomas 2011), wherein detrital zircons with absolute ages that are the same as the depositional ages of strata in which they occur are rare or absent in Paleozoic clastic wedges of eastern Laurentia. For example, the Middle Ordovician (Taconian) clastic wedge of the Appalachian basin does not contain Ordovician-aged detrital zircons, and Late Devonian Neo-Acadian clastic wedge sediments do not contain Devonian-aged detrital zircons. It is not until the Devonian (Acadian orogeny) and Pennsylvanian (Alleghanian orogeny) that Middle Ordovician detrital zircons appear in Acadian and Alleghanian clastic wedges to define a Taconian age mode. Apparently, a subsequent collisional event is required to exhume crystalline rocks formed in the prior orogenic phase in order that the crystalline rocks can generate detrital zircons sourced from the previous orogenic event. 
The dominant age mode in both the Kentucky and Ohio Middle Run detrital zircon age spectra (fig. $5 \mathrm{~A}$ ) also requires explanation, as the majority of measured ages fall between the two major zircongenerating events in eastern Laurentia: the Shawinigan phase of the Grenville orogeny (ca. 1140-1180 Ma, above) and Midcontinent rifting (1115-1085 Ma; Davis and Paces 1990; Paces and Miller 1993; Vervoort et al. 2007; fig. 5B). Two possible scenarios could explain this major age mode:

1. The Grenville Province exposed in central and west Texas includes a late granite suite that consists of plutons ranging from 1130 to $1080 \mathrm{Ma}(\mathrm{U}-\mathrm{Pb}$ TIMS ages) and intrudes older magmatic/metamorphic suites of $1290-1230$ and $1380-1320 \mathrm{Ma}$ age (Mosher 1998; fig. 6B). Sandstones of late Mesoproterozoic and late Paleozoic age in west Texas exhibit a dominant detrital zircon age mode at $1120 \mathrm{Ma}$, interpreted to reflect a general southwest Grenville and midcontinent provenance (Gleason et al. 2007; Spencer et al. 2014; fig. 6B). Although there is some agreement between the detrital zircon age spectra of the Texas basement/clastic sequences and the Middle Run Formation (fig. 5B), and such a distal provenance cannot be ruled out, the latter would preclude major sediment input from the more proximal Grenville highlands represented by basement rocks just east of the Grenville Front, as discussed above, that were undergoing active uplift and exhumation.

2. The dominant age mode could consist of two overlapping age populations that cannot be resolved geochronologically. The dominant age mode includes $\sim 90$ grains with ages that are the same within $1 \sigma$ precision (10-20 My) as the age range of Midcontinent rifting and magmatic activity (1115$1085 \mathrm{Ma}$ ). This age range was also assumed to be the age of East Continent Rift Basin formation and magmatism (Wickstrom et al. 1992). Evidence exists for minor Grenville magmatism in this narrow time window, and some of these detrital zircons could be Grenvillian, but, in contrast to southwestern Laurentia, this is a noted age gap within the Grenville orogenic cycle of eastern Laurentia (Rivers 1997, 2008; Southworth et al. 2010; Aleinikoff and Walsh 2017; fig. 5B). Therefore, although the youngest detrital zircon ages require a depositional age for the western Kentucky litharenite that postdates Midcontinent rifting, the presence of many detrital zircon grains with ages within error of Midcontinent Rift magmatism permits one of the dominant sources to be Midcontinent volcanic rocks or recycled sediments from the Midcontinent/East Continent Rift Basins (also see Craddock et al. 2013 and Malone et al. 2016 for detrital zircon geochronology of type sections of Midcontinent Keweenawan synrift sediments). A definitive test for the presence of detrital zircon derived from Midcontinent/East Continent volcanic rocks versus zircon derived from Grenville magmatic and metamorphic rocks in the Middle Run would be combined U/Pb geochronology and U-Th-Sm/He thermochronology ("double dating"; Rahl et al. 2003; Reiners et al. 2005) of the ca. 1080-1180 Ma detrital zircon grains. U-Pb ages of Grenville zircons should be greater than U-Th-Sm/ He ages by approximately $100 \mathrm{My}$ as a result of the time between magmatic crystallization and cooling through the He closure temperature $\left(T_{\mathrm{c}}\right)$ for zircon during exhumation $\left(\sim 190^{\circ} \mathrm{C}\right)$. There should be no resolvable difference in age for the two systems for detrital zircon derived from volcanic rocks or shallowly emplaced intrusions due to instantaneous or rapid cooling through the $T_{\mathrm{c}}$. Double dating would also permit distinction between detrital zircon of southwest Grenville provenance and that of Midcontinent/East Continent provenance.

Orthogneiss. The interpreted crystallization age of the orthogneiss protolith ( 1450 Ma) is the same as the age of magmatic protoliths of high-grade orthogneisses that constitute basement lithotectonic domains in the Central Gneiss Belt of the Grenville Province of southwestern Ontario (Rivers 1997; Slagstad et al. 2009). Grenville crust in southwestern Ontario is now correlated with ca. $1450 \mathrm{Ma}$ juvenile crust of the EGR Province of the US midcontinent region (van Breemen and Davidson 1988; Van Schmus et al. 1996; Whitmeyer and Karlstrom 2007; Slagstad et al. 2009; Fisher et al. 2010; Bickford et al. 2015; fig. 1). A basement orthogneiss similar in lithology, inferred age (crystallization at ca. $1450 \mathrm{Ma}$ and metamorphism at ca. $1000 \mathrm{Ma}$ ), and tectonic setting (east of the Grenville Front) is reported for a drill core from southernmost Ohio located $32 \mathrm{~km}$ from the site of our sample (Petersson et al. 2015; fig. 2, location D). Thus, these occurrences confirm that rocks of EGR age (magmatic rocks and their high-grade metamorphic equivalents) comprise crust on both sides of the Grenville Front, consistent with the interpretation that the Grenville Front in the eastern midcontinent is primarily a deformation front and not a terrane boundary or suture (e.g., Whitmeyer and Karlstrom 2007). The ca. 1020 Ma generation of metamorphic zircon in this sample correlates with the latest Ottawan phase of high-grade regional metamorphism throughout the Grenville Province in eastern Laurentia (Rivers 1997, 2008; Southworth et al. 2010; Tollo et al. 2010; McLelland et al. 2013). This metamorphic age is indistinguishable from the age of the youngest detrital zircons in the Kentucky litharenite and supports the interpretation based on U-Pb metamorphic and ${ }^{40} \mathrm{Ar}-{ }^{39} \mathrm{Ar}$ cooling ages that crust east of 
the Grenville front was just beginning to generate detrital zircons of that age during Middle Run sedimentation.

\section{Conclusions}

On the basis of the detrital zircon ages and detrital mineralogy, the litharenite in western Kentucky is proposed to be a distal correlative of the Middle Run Formation from the type section in Ohio. The maximum depositional age (ca. $1020 \mathrm{Ma}$ ) precludes its being a correlative of synrift clastic sequences filling the ca. $1100 \mathrm{Ma}$ Midcontinent (Craddock et al. 2013) or East Continent Rift system basins (assuming that $\sim 1100 \mathrm{Ma}$ is the only time of rifting). Multiple detrital zircon age modes are consistent with ultimate derivation of zircon from various Mesoproterozoic central Laurentian (Southern and Eastern Granite-Rhyolite, Mazatzal, Yavapai) and eastern Laurentian (Grenville Elzivirian and Shawinigan) terranes. The greatest number of detrital zircon grains (ages of 1080-1180 Ma), the maximum depositional age, the framework and heavy-detrital-mineral modes, and the proximity to the exhuming Grenville orogen are consistent with (1) some sediment being derived from a Grenville highland, which was exhuming Shawinigan-aged (1140-1180 Ma) crystalline rocks, being transported into a foreland basin developed upon previously rifted EGR crust; and (2) the majority of sediment being derived from Midcontinent Rift volcanic rocks or recycling of detrital zircon from synrift sediments (1080-1120 Ma). The rarity of Ottawanaged (1020-1080 Ma) detrital zircons in the Middle Run sequence and the ca. $1020 \mathrm{Ma}$ metamorphic age of orthogneiss dated here indicate that granites and gneisses generated during the Ottawan phase of the Grenville orogeny were just beginning to be exhumed during Middle Run basin time. Alternatively, syn- to late Ottawan sediments could have completely bypassed the Kentucky and Ohio Middle Run basins to ultimately be deposited as distal clastic sequences in Arctic Canada and the western United States that represent the "great Grenvillian sedimentation episode" proposed by Rainbird et al. (2012). Other similar red bed sequences in the midcontinent that are capped by basalt, contain demonstrable volcanic clasts, and are likely to be synrift sediments should be older ( 1100 Ma) than the Middle Run litharenites but require detrital zircon U-Pb geochronology to test this hypothesis.

\section{A C K N O W LE D G M E N T S}

The upgrade of the CAMECA SX50 at the University of Kentucky (UK) was supported by National Science Foundation (NSF) Division of Earth Sciences Instrumentation and Facilities grant 0824714. The SEM at UK was acquired with NSF Instrumentation and Facilities grant 1551342 and with financial support of the Kentucky Geological Survey. Kentucky Geological Survey support for core acquisition was in part provided by the Commonwealth of Kentucky, Energy Independence and Incentives Act of 2007, and the US Department of Energy, National Energy Technology Laboratory. We appreciate the patient instruction of M. Pecha and the staff of the Arizona Laserchron laboratory and of A. Schmitt, formerly of the UCLA Keck SIMS laboratory, during our visits to their facilities.

\section{REFEREN C E S C I T E D}

Aleinikoff, J. N., and Walsh, G. J. 2017. New evidence for late to post-Shawinigan intrusion of the Hawkeye granite gneiss and Lyon Mountain granite gneiss, Adirondack Highlands, NY. Geol. Soc. Am. Abstr. Program 49(2). doi:10.1130/abs/2017NE-290044.

Ashwal, L. D.; Tucker, R. D.; and Zinner, E. K. 1999. Slow cooling of deep crustal granulites and $\mathrm{Pb}$-loss in zircon. Geochim. Cosmochim. Acta 63:2839-2851.

Baranoski, M. T.; Dean, S. L.; Wicks, J. L.; and Brown, V. M. 2009. Unconformity-bounded seismic reflection sequences define Grenville-age rift system and foreland basins beneath the Phanerozoic in Ohio. Geosphere 5(2):140-151.

Bass, M. N. 1960. Grenville boundary in Ohio. I. Geol. 68:673-677.
Becker, T. P.; Thomas, W. A.; Samson, S. D.; and Gehrels, G. E. 2005. Detrital zircon evidence of Laurentian crustal dominance in the lower Pennsylvanian deposits of the Alleghanian clastic wedge in eastern North America. Sediment. Geol. 182:59-86.

Bickford, M. E.; Van Schmus, W. R.; Karlstrom, K. E.; Mueller, P. A.; and Kamenov, G. D. 2015. Mesoproterozoic-trans-Laurentian magmatism: a synthesis of continent-wide age distributions, new SIMS $\mathrm{U}-\mathrm{Pb}$ ages, zircon saturation temperatures, and $\mathrm{Hf}$ and $\mathrm{Nd}$ isotopic compositions. Precambrian Res. 265:286-312.

Bowersox, J. R., and Williams, D. A. 2014. Geology of the Kentucky Geological Survey Marvin Blan No. 1 well, east-central Hancock County, Kentucky. Ky. Geol. Surv. Rep. Investig. 25, Ser. XII, 22 p. 
Carr, S. D.; Easton, R. M.; Jamieson, R. A.; and Culshaw, N. G. 2000. Geologic transect across the Grenville orogen of Ontario and New York. Can. I. Earth Sci. 37:193-216.

Chakraborty, S.; Moecher, D. P.; and Samson, S. D. 2012. Provenance of the lower Ocoee Supergroup, eastern Great Smoky Mountains. Geol. Soc. Am. Bull. 124:1278-1292.

Chiarenzelli, J. R., and McLelland, J. M. 1993. Granulite facies metamorphism, palaeo-isotherms and disturbance of the U-Pb systematics of zircon in anorogenic plutonic rocks from the Adirondack Highlands. I. Metamorph. Geol. 11:59-70.

Corfu, F.; Hanchar, J. M.; Hoskin, P. W. O.; and Kinny, P. 2003. Atlas of zircon textures. Rev. Mineral. Geochem. 53:469-500.

Cosca, M. A.; Sutter, J. F.; and Essene, E. J. 1991. Uplift/ erosion history of the Grenville orogen, Ontario: constraints from ${ }^{40} \mathrm{Ar} /{ }^{39} \mathrm{Ar}$ thermochronology. Tectonics 10:959-977.

Craddock, J. P.; Konstaninou, A.; Vervoort, J. D.; Wirth, K. R.; Davidson, C.; Finley-Blasi, L.; Juda, N. A.; and Walker, E. 2013. Detrital zircon provenance of the Mesoproterozoic Midcontinent Rift, Lake Superior region, U.S.A. I. Geol. 121:57-73.

Dahl, P. S.; Pomfrey, M. E.; and Foland, K. A. 2004. Slow cooling and apparent tilting of the Adirondack Lowlands, Grenville Province, New York, based on ${ }^{40} \mathrm{Ar} /{ }^{39} \mathrm{Ar}$ ages. In Tollo, R. P.; Corriveau, L.; McLelland, J.; and Bartholomew, M. J., eds. Proterozoic tectonic evolution of the Grenville orogen in North America. Geol. Soc. Am. Mem. 197:299-323.

Davis, D. W., and Paces, J. B. 1990. Time resolution of geologic events on the Keweenaw Peninsula and implications for the development of the Midcontinent rift system. Earth Planet. Sci. Lett. 97:54-64.

Dickinson, W. R., and Gehrels, G. E. 2009. Use of U$\mathrm{Pb}$ ages of detrital zircons to infer maximum depositional ages of strata: a test against a Colorado Plateau Mesozoic database. Earth Planet. Sci. Lett. 288:115-125.

Drahovzal, J. A. 1997. Proterozoic sequences and their implications for Precambrian and Cambrian geologic evolution of western Kentucky: evidence from seismic reflection data. Seismol. Res. Lett. 68:553566.

Eriksson, K. A.; Campbell, I. H.; Palin, J. M.; and Allen, C. M. 2003. Predominance of Grenvillian magmatism recorded in detrital zircons from modern Appalachian rivers. I. Geol. 111:707-717.

Eriksson, K. A.; Campbell, I. H.; Palin, J. M.; Allen, C. M.; and Bock, B. 2004. Evidence for multiple recycling in Neoproterozoic through Pennsylvanian sedimentary rocks of the central Appalachian basin. I. Geol. 112:261-276.

Fisher, C. M.; Loewy, S. L.; Miller, C. F.; Berquist, P.; Van Schmus, W. R.; Hatcher, R. D., Jr.; Wooden, J. L.; and Fullagar, P. D. 2010. Whole-rock Pb and Sm-Nd isotopic constraints on the growth of southeastern
Laurentia during Grenvillian orogenesis. Geol. Soc. Am. Bull. 122:1646-1659.

Gehrels, G. E.; Valencia, V.; and Ruiz, J. 2008. Enhanced precision, accuracy, efficiency, and spatial resolution of $\mathrm{U}-\mathrm{Pb}$ ages by laser ablation-multicollector-inductively coupled plasma-mass spectrometry. Geochem. Geophys. Geosyst. 9:Q03017. doi:10.1029/2007GC001805.

Gleason, J. D.; Gehrels, G. E.; Dickinson, W. R.; Patchett, P. J.; and Kring, D. A. 2007. Laurentian sources for detrital zircon grains in turbidite and deltaic sandstones of the Pennsylvanian Haymond Formation, Marathon assemblages, west Texas, U.S.A.I. Sediment. Res. 77:888-900.

Halpin, J. A.; Daczko, N. R.; Milan, L. A.; and Clarke, G. L. 2012. Decoding near-concordant U-Pb zircon ages spanning several hundred million years: recrystallization, metamictisation, or diffusion? Contrib. Mineral. Petrol. 163:67-85.

Hauser, E. C. 1993. Grenville foreland thrust belt hidden beneath the eastern U.S. midcontinent. Geology 21:61-64.

- 1996. Mid-continent rifting in a Grenville embrace. In van der Pluijm, B., and Catacosinos, P. A., eds. Basement and basins of eastern North America. Geol. Soc. Am. Spec. Pap. 308:67-75.

Hickman, J. B. 2011. Structural evolution of an intracratonic rift system; Mississippi Valley Graben, Rough Creek Graben, and Rome Trough of Kentucky, USA. $\mathrm{PhD}$ dissertation, University of Kentucky, Lexington.

Hoppe, W. J.; Montgomery, C. W.; and Van Schmus, W. R. 1983. Age and significance of Precambrian basement samples from northern Illinois and adjacent states. I. Geophvs. Res. Solid Earth 88:7276-7286.

Hynes, A., and Rivers, T. 2010. Protracted continental collision-evidence from the Grenville orogen. Can. I. Earth Sci. 47:591-620.

Johnson, T. A.; Vervoort, J. F.; Ramsey, M. J.; Southworth, S.; Aleinikoff, J. N.; and Tollo, R. P. 2017. Constraints on the timing and duration of the Grenville orogeny. Geol. Soc. Am. Abstr. Program 49(3). doi:10.1130/abs/2017SE-290920.

Keller, G. R.; Lidiak, E. G.; Hinze, W. J.; and Braile, L. W. 1983. The role of rifting in the tectonic development of the midcontinent, USA. Tectonophysics 94:391-412.

Krogh, T. E. 1994. Precise U-Pb ages for Grenvillian and pre-Grenvillian thrusting of Proterozoic and Archean metamorphic assemblages in the Grenville Front tectonic zone, Canada. Tectonics 13:963982.

Lidiak, E. G.; Marvin, R. F.; Thomas, H. H.; and Bass, M. N. 1966. Geochronology of the midcontinent region, United States. 4. Eastern region. I. Geophys. Res. 71:5427-5438.

Ludwig, K. R. 2008. Isoplot 3.70: a geochronological toolkit for Microsoft Excel. Spec. Publ. 4. Berkeley, CA, Berkeley Geochronology Center.

Malone, D. H.; Stein, C. A.; Craddock, J. P.; Kley, J.; Stein, S.; and Malone, J. 2016. Maximum deposi- 
tional age of the Neoproterozoic Jacobsville Sandstone, Michigan: implications for the evolution of the Midcontinent Rift. Geosphere 12:1271-1282.

McLelland, J. M., and Daly, J. S. 1996. The Grenville orogenic cycle (ca. 1350-1000 Ma): an Adirondack perspective. Tectonophysics 265:1-28.

McLelland, J. M.; Selleck, B. W.; and Bickford, M. E. 2013. Tectonic evolution of the Adirondack Mountains and Grenville Orogen inliers within the USA. Geosci. Canada 40:318-352. doi:10.12789/geocanj.2013 .40 .022 .

Mezger, K., and Krogstad, E. J. 1997. Interpretation of discordant U-Pb zircon ages: an evaluation. I. Metamorph. Geol. 15:127-140.

Mezger, K.; Rawnsley, C. M.; Bohlen, S. R.; and Hanson, G. N. 1991. U-Pb garnet, sphene, monazite, and rutile ages: implications for the duration of high-grade metamorphism and cooling histories, Adirondack Mts., New York. I. Geol. 99:415-428.

Moecher, D. P., and Samson, S. D. 2006. Differential Grenville zircon fertility of source terranes and natural bias in the detrital zircon record: implications for sedimentary provenance analysis. Earth Planet. Sci. Lett. 247:252-266.

Mosher, S. 1998. Tectonic evolution of the southern Laurentian Grenville orogenic belt. Geol. Soc. Am. Bull. 110:1357-1375.

Paces, J. B., and Miller, J. D., Jr. 1993. Precise U-Pb ages of Duluth Complex and related mafic intrusions, northeastern Minnesota: geochronological insights to physical, petrogenetic, paleomagnetic, and tectonomagmatic processes associated with the $1.1 \mathrm{Ga}$ Midcontinent Rift system. I. Geophys. Res. Solid Earth 98:13,997-14,013.

Park, H.; Barbeau, D. L., Jr.; Rickenbaker, A.; BachmanKrug, D.; and Gehrels, G. 2010. Application of foreland basin detrital-zircon geochronology to the reconstruction of the southern and central Appalachian orogen. I. Geol. 118:23-44.

Petersson, A.; Scherstén, A.; Andersson, J.; Whitehouse, M. J.; and Baranoski, M. T. 2015. Zircon U-Pb, Hf and O isotope constraints on growth versus reworking of continental crust in the subsurface Grenville Orogen, Ohio, USA. Precambrian Res. 265:313-327.

Rahl, J. M.; Reiners, P. W.; Campbell, I. H.; Nicolescu, S.; and Allen, C. M. 2003. Combined single-grain $(\mathrm{U}-\mathrm{Th}) / \mathrm{He}$ and $\mathrm{U} / \mathrm{Pb}$ dating of detrital zircons from the Navajo Sandstone, Utah. Geology 31:761-764.

Rainbird, R.; Cawood, P.; and Gehrels, G. 2012. The great Grenvillian sedimentation episode: record of supercontinent Rodinia's assembly. In Busby, C., and Azor, A., eds. Tectonics of sedimentary basins: recent advances. Chichester, Wiley, p. 583-601.

Reiners, P. W.; Campbell, I. H.; Nicolescu, S.; Allen, C. M.; Hourigan, J. K.; Garver, J. I.; Mattinson, J. M.; and Cowan, D. S. 2005. (U-Th)/(He-Pb) double dating of detrital zircons. Am. I. Sci. 305:259-311.
Rivers, T. 1997. Lithotectonic elements of the Grenville Province: review and tectonic implications. Precambrian Res. 86:117-154.

. 2008. Assembly and preservation of lower, mid, and upper orogenic crust in the Grenville Provinceimplications for the evolution of large hot longduration orogens. Precambrian Res. 167:237-259.

Santos, J. O. S.; Hartmann, L. A.; McHaughton, N. J.; Easton, R. M.; Rea, R. G.; and Potter, P. E. 2002. Sensitive high resolution ion microprobe (SHRIMP) detrital zircon geochronology provides new evidence for a hidden Neoproterozoic foreland basin to the Grenville Orogen in the eastern Midwest, U. S. A. Can. I. Earth Sci. 39:1505-1515.

Satkoski, A. M.; Samson, S. D.; Southworth, S.; and Wilkenson, B. H. 2012. Detrital zircon ages from the Neoproterozoic-Cambrian rift-to-drift sequence of the eastern US. Geol. Soc. Am. Abstr. Program 44(7):379.

Schmitt, A. K.; Grove, M.; Harrison, T. M.; Lovera, O.; Hulen, J.; and Walters, M. 2003. The Geysers-Cobb Mountain magma system, California (Part 1): U-Pb zircon ages of volcanic rocks, conditions of zircon crystallization and magma residence times. Geochim. Cosmochim. Acta 67:3423-3442.

Schmitz, M. D.; Bowring, S. A.; and Ireland, T. R. 2003. Evaluation of the Duluth Complex anorthositic series (AS3) zircon as a U-Pb geochronological standard: new high- precision isotope dilution thermal ionization mass spectrometry results. Geochim. Cosmochim. Acta 67:3665-3672.

Shrake, D. L. 1991. The Middle Run Formation: a subsurface stratigraphic unit in southwestern Ohio. Ohio J. Sci. 91:49-55.

Slagstad, T.; Culshaw, N. G.; Daly, J. S.; and Jamieson, R. A. 2009. Western Grenville Province holds key to midcontinental Granite-Rhyolite Province enigma. Terra Nova 21:181-187.

Southworth, S.; Aleinikoff, J. N.; Tollo, R. P.; Bailey, C. M.; Burton, W. C.; Hackley, P. C.; and Fanning, M. C. 2010. Mesoproterozoic magmatism and deformation in the northern Blue Ridge, Virginia and Maryland: application of SHRIMP U-Pb geochronology and integrated field studies in the definition of Grenvillian tectonic history. In Tollo, R. P.; Bartholomew, M. J.; Hibbard, J. P.; and Karabinos, P. M., eds. From Rodinia to Pangea: the lithotectonic record of the Appalachian region. Geol. Soc. Am. Mem. 206:795-836.

Spencer, C. J.; Prave, A. R.; Cawood, P. A.; and Roberts, N. M. W. 2014. Detrital zircon geochronology of the Grenville/Llano foreland and basal Sauk Sequence in west Texas, USA. Geol. Soc. Am. Bull. 126:1117-1128.

Stark, T. J. 1997. East Continent Rift Complex: evidence and conclusions. In Ojakangas, R. W.; Dickas, A. B.; and Green, J. C., eds. Middle Proterozoic to Cambrian rifting, central North America. Geol. Soc. Am. Spec. Pap. 312:253-266. 
Stein, C. A.; Kley, J.; Stein, S.; Hindle, D.; and Keller, G. R. 2015. North America's Midcontinent Rift: when rift met LIP. Geosphere 11:1607-1616.

Thomas, W. A. 2011. Detrital-zircon geochronology and sedimentary provenance. Lithosphere 3:304-308.

Thomas, W. A.; Becker, T. P.; Samson, S. D.; and Hamilton, M. A. 2004. Detrital zircon evidence of a recycled orogenic foreland provenance for Alleghanian clastic-wedge sandstones. I. Geol. 112:23-27.

Tollo, R. P.; Aleinikoff, J. N.; Wooden, J. L.; Mazdab, F. K.; Southworth, S.; and Fanning, M. C. 2010. Thermomagmatic evolution of Mesoproterozoic crust in the Blue Ridge of SW Virginia and NW North Carolina: evidence from $\mathrm{U}-\mathrm{Pb}$ geochronology and zircon geothermometry. In Tollo, R. P.; Bartholomew, M. J.; Hibbard, J. P.; and Karabinos, P. M., eds. From Rodinia to Pangea: the lithotectonic record of the Appalachian region. Geol. Soc. Am. Mem. 206:859-896.

van Breemen, O., and Davidson, A. 1988. Northeast extension of Proterozoic terranes of mid-continental North America. Geol. Soc. Am. Bull. 100:630-638.

Van Schmus, W. R.; Bickford, M. E.; and Turek, A. 1996. Proterozoic geology of the east-central midcontinent basement. In van der Pluijm, B. A., and Catacosinos, P. A., eds. Basement and basins of eastern North America. Geol. Soc. Am. Spec. Pap. 308:7-32.
Vervoort, J. D.; Wirth, K.; Kennedy, B.; Sandland, T.; and Harpp, K. S. 2007. The magmatic evolution of the midcontinent rift: new geochronologic and geochemical evidence from felsic magmatism. Precambrian Res. 157:235-268.

Whitehouse, M. J.; Ravindra Kumar, G. R.; and Rimša, A. 2014. Behaviour of radiogenic $\mathrm{Pb}$ in zircon during ultrahigh-temperature metamorphism: an ion imaging and ion tomography case study from the Kerala Khondalite Belt, southern India. Contrib. Mineral. Petrol. 168:1042. doi:10.1007/s00410-014-1042-2.

Whitmeyer, S. J., and Karlstrom, K. E. 2007. Tectonic model for the Proterozoic growth of North America. Geosphere 3:220-259.

Wickstrom, L. H.; Drahovzal, J. A.; and Keith, B. D. 1992. The geology and geophysics of the East Continent Rift Basin: report of Cincinnati Arch Consortium. Indiana Geol. Surv. Open-File Study 92-04, $103 \mathrm{p}$.

Yonkee, W. A.; Dehler, C. D.; Link, P. K.; Balgord, E. A.; Keeley, J. A.; Hayes, D. S.; Wells, M. I.; Fanning, C. M.; and Johnston, S. M. 2014. Tectono-stratigraphic framework of Neoproterozoic to Cambrian strata, west-central U. S.: protracted rifting, glaciation, and evolution of the North American Cordilleran margin. Earth-Sci. Rev. 136:59-95. 